\title{
Screening Nature in Walt Disney's Bambi (1942) and Dr. Seuss's The Lorax (1972): An Ecocritical Approach to Enviro-toons
}

\author{
Dr. Marwa Essam Eldin Fahmy Alkhayat \\ Associate Professor of Comparative Literature \& Criticism, \\ Faculty of Languages \& Translation, English Department, Ahram \\ Canadian University, Egypt.
}

\begin{abstract}
The present study is an attempt to fill in a gap in Ecocriticism which until recently has focused on literature defined as Nature Writing; poetry, fiction and drama. Yet, with the move toward ecocritical Film Studies, there is a place for work on animated feature films. The premise of the study is the ethical and environmental implications as exemplified in the two selected enviro-toons: Disney's Bambi (1942) and Dr. Seuss's The Lorax (1972). The depiction of wilderness and the representation of nonhuman animals provide a rich context to investigate ideology and power to explore oppressive practices of contemporary societies. The selected enviro-toons strongly articulate ecological crisis; hunting, species loss, pollution, deforestation and overproduction. The Lorax exposes overconsumption that is driven by the capitalism's profit motive and the pro-industrial character the Once-ler's "jobs jobs -jobs" rhetoric. On the other hand, Bambi stands for a romanticized environment with the perspective that marks nature as an ecological sublime since the wilderness trope is worthy of awe and wonder. The peculiar language of animation is deliberately defined by multiple distinctions. Animation is an aesthetically determined lexis, interpreted by different animators, hence, animation bears a distinct authorial
\end{abstract}


signature and a unique studio style. Disney's 'realist' style fits into orthodox animation while that of Dr. Seuss is 'abstract' and 'experimental'. The focus is on the poetics of envirotoons, that is, not only what cartoons show but how they illustrate ecocritical sensibility and how it affects the way of 'seeing' and understanding the human/nonhuman world. Not only does Dr. Seuss tell fantastical tales of far-away places but he also illustrates a unique visual language that carries his stories to new heights of artistic expression. Surrealism provides the foundation from which he builds the structure of The Lorax. The structure is analogous to a dream-like state to underlie hidden sentiments beyond the orthodoxies of language. In contrast, Bambi is a monologic biography in photographic realism. Disney's mimesis and linear structure do not require deep interpretation and since it is only a warning with no handy action plan, there is no path to human redemption to exist in a world that upholds 'strong anthropocentrism' as a discourse of human dominion over nature. Finally, Ecomedia Studies is a promising pop culture field not only geared to adolescents and children, but also to human community to be aesthetically interpreted against a monolithic approach.

\section{Keywords:}

Animation Aesthetics- Orthodox animation- Experimental animation- Enviro-toons- Ecocriticism- DisneyequeSeussology. 
Screening Nature in Walt Disney's Bambi (1942) and Dr. Seuss's The Lorax

(1972): An Ecocritical Approach to Enviro-toons

Dr. Marwa Essam Eldin Fahmy Alkhayat

مجلة وادي النيل للاراسات والبحوث الإنسانية والاجتماعية والتربوية (مجلة علمية محكمة)

تصوير الطبيعة في أفلام البيئي- تون: بامبى (ץ 9 (1)

لولت ديزنى ولوراكس (9VY I ) للاكتور سوس أنموذجًا

د. مروه عصام الدين فهمى الخياط

أستاذ الادب المقارن والنقد المساعد، كلية اللغات والترجمة

قسم اللغة الإنجليزية، جامعة الأهرام الكندية، مصر .

الملخص:

تعد الدراسة الحالية محاولة لمله الفجوة في النقد البيئي Ecocriticism التي

ركزت حتى وقت قريب على أدب الطبيعة المتمثل في الشعر والرواية والدراما، ولم

تنل أفلام الكرتون اهتمام النقد البيأي، رغم أنها بدأت تتحرك نحو إنتاج الأفلام

البيئية بشكل واعد. وتطرح هذه الدراسـة فرضية تتمحور حول الآثار الأخلاقية

والبيئية المتمثلة في أفلام بيئي- تون المختارة؛ بامبي (Y 9 ( ) لديزني، و لوراكس

(9VY ( ) للدكتور سوس، فقد خلق تصـوير الحياة البريـة والحيوانات سياقًا غنيًا

لمناقشـة العلاقـة بين الإيديولوجيـة المهيمــة واستخدام القوة لفضـح ملامـح القــع

المتمثلة في المجتمع الاستهلاكي المعاصر • ويعبر فيلما البيئي- تون سالفا الذكر

عن مشاكل بيئية كارثية؛ من مثل الصيد، وفقدان الأنواع، والتلوث، وإزالة الغابات،

والإفراط في الإنتاج...الخ. ويعد الدافع الاستهلاكي نتيجةً طبيعيةً لهوس الربح

الرأسمالي الصناعي الذي يتجلى بشكل كبير في رفع شعار "وظائف، وظائف،

وظـائف" الخطابى الذى تبنته الثخصـية الرأسـمالية وانس- لير في لـوركس. 
ويمثل أمير الغابة في بامبي، من ناحية أخرى الحس البيئي السامي، أي الطبيعية البرية التي ترتقي لمكانة العبادة والجلالمة المهيبة. ويسعى البحث الى إبراز اللغة المتفردة لتقنيات الرسوم المتحركة التي تمثل سردًا فنيًا وجماليًا يعكس المحتوى الثقافى لرسـام الكارتون. وجدير بالذكر أن لكل مؤلف أو رسـام كارتون بصـته الفنيـة الخاصـة بـه التي تميز الاستوديو الفني الذى ينتمى إليـه. لقد تم اختيـار بامبي لإبراز الأسلوب الواقعي في الرسوم المتحركة التي اشتهر بها "والت ديزني" الذى تبنى المفهوم الواقعي الى حد إضفاء الصفات البشرية على الثخصيات، بينما يتفرد الدكتور سوس فى اتباع الأسلوب التجريدي والتجريبي الذي ظهر جليًا فى رسم شخصيات غير واقعية وابتكار أسماء شخصيات وأمـاكن غير مألوفة وغريبة فى لوراكس. وعليه يرتكز البحث على إبراز "شعرية " Poetics الرسوم المتحركة لتقديم تحليلاً وافيًا عن الأسـاليب الفنية المستخدمة ولغة صورة الكارتون لمناقشة قضايا نقدية بيئية تبلور العلاقة بين الإنسان والطبيعة المتمثلة فى الحيوان والنباتات ومعالم الطبيعة من جبال وسهول ووديان وأنهار . الكلمات المفاتيح: جماليات فن الرسوم المتحركة، أفلام البيئي- تون، النقد البيئي، مدرسـة ديزني الواقعية للرسوم المتحركة، أسلوب الدكتور سوس في الرسوم المتحركة التجربية 
Screening Nature in Walt Disney's Bambi (1942) and Dr. Seuss's The Lorax (1972): An Ecocritical Approach to Enviro-toons

Dr. Marwa Essam Eldin Fahmy Alkhayat

مجلة وادي النيل للاراسات والبحوث الإنسانية والاجتماعية والتربوية (مجلة علمية محكمة)

\section{Introduction}

The term 'environment' has come to prominence to conceptualize the physical world. In Writing for an Endangered World: Literature, Culture and Environment (2001), Lawrence Buell's enmeshment of nature and culture suggests an environment that is an amalgamation of the '"brown landscapes' of industrialization and the 'green landscapes' of the natural, physical world" (7). The physical environment is still recognizable as a force that influences humankind with cyclones, floods, and droughts therefore, the environment is not static but it is in a constant state of flux, a "mutual constructivism" where the environment is shaped by, but also helps shape culture" (Buell 2001: 6). In The Environment Imagination (1995), Buell argues that the "environment and place are as much social, cultural and ideological entities as they are physical one" (36). Ecocritical awareness of the non-human world has begun with the delineation of nature first proposed by Romantic writers in the late eighteenth and early nineteenth centuries: they "hated how industrialization made previously beautiful places ugly, and they rejected the vulgarity of those who made money in trade" (Russell 653). Modern environmental criticism promotes antiindustrial argument "deploying concepts of nature as a moral and psychic norm" (Italics mine Clark 18). Pastoral is a universal trope of environmental imagination and it has become almost "synonymous with the idea of (re)turn to a less urbanized, more 'natural' state of existence" activating "green consciousness" (Buell 1995: 31).

It is worth mentioning that the Romantic ecology is not simply a retreat from society into spiritual transcendence and it is "not a flight from a material world", but it is "an attempt to enable mankind to live better in the material world by entering into harmony with the environment" (Bate 40). This 
مجلة وادي النيل للار اسات والبحوث الإسانية والاجتماعية والتربوية (مجلة علمية محكمة)

(ISSN : 2536 - 9555)

proto-ecological anti-industrial approach endorses the naturalness of the local life and rebuts the view of the natural world as silenced 'Other'. Since ancient times, European and other cultures have used universal tropes and myths that have shaped human environmental imagination such as Garden, Wilderness, and Virgin Land to describe their relationship with land and nature. Ecocritics speak for animals or nonhuman creatures whose exploitation is often closely interlinked with the exploitation of nature. Ecocriticism provides an outstanding fusion of literary, ecological, scientific and philosophical perceptions, as William Rueckert proposes the notion of "literary ecology":

The conceptual and practical problem is to find the grounds upon which the two communities - the human, the natural - can coexist, cooperate, and flourish in the biosphere. All of the most serious and thoughtful ecologists ... have tried to develop ecological visions which can be translated into social, economic, political, and individual programs ... All this may seem rather remote from creating, reading, teaching, and writing about literature; but in fact, it is not. I invoke here the first Law of Ecology: 'Everything is connected to everything else'. (Italics mine 71)

Literature, consequently, can be examined not only in its specific entity, but, most importantly, in its association with other fields opening new critical routes to be explored. The arena of Ecocriticism has grown within the field of literature studies establishing itself as a vital discipline of the environmental humanities. There has been, for example, a proliferation of environmentally themed children's literature (in genres including fiction, non-fiction, films and picture books) over the last year of the twentieth century and into the 
Screening Nature in Walt Disney's Bambi (1942) and Dr. Seuss's The Lorax (1972): An Ecocritical Approach to Enviro-toons

Dr. Marwa Essam Eldin Fahmy Alkhayat

مجلة وادي النيل للاراسات والبحوث الإنسانية والاجتماعية والتربوية (مجلة علمية محكمة)

twenty-first to address ecological issues seen as cautionary tales: "children's literature offers one of the most extensive sources for the study of ideas about nature, the environment sources, ecology and the role of humans in relation to all of these" (Lesnik-Oberstein 216). The depiction of wilderness and the representation of nonhuman animals provide a rich context to investigate ideology and power to explore oppressive practices of contemporary societies.

\subsection{Rationale and Scope}

The present critique of enviro-toons aims at providing a rereading of ecological issues through eco-media lens to examine a plethora of themes; the human-nature conflict to expose man's exploitation of the natural resources, to explore nature and natural landscapes in relation to cultural/historical contexts and finally to propose the human-nature interdependence to maintain a harmonious existence. The two selected enviro-toons strongly articulate ecological crisis; hunting, species loss, pollution, deforestation and overproduction. The Lorax exposes overconsumption that is driven by the capitalism's profit motive and the pro-industrial character the Once-ler's "jobs-jobs-jobs" rhetoric. On the other hand, Bambi stands for a romanticized environment with the perspective that marks nature as an ecological sublime since the wilderness trope is worthy of awe and wonder.

The peculiar language of animation is deliberately defined by multiple distinctions, thereby; the poetics of enviro-toons are explored to address the following questions: 1) How do cartoons work on viewers? How do they generate meaning and affect sentiments, emotional responses, desires, motivations and sensibilities? 2) Is nature given a perspective in the enviro-toons? Do we see through the eyes of the animals or other creatures? Is this supposed to be realistic or 
مجلة وادي النيل للاراسات والبحوث الإنسانية والاجتماعية والتربوية (مجلة علمية محكمة)

(ISSN : 2536 - 9555)

not? What effect does this have? 3) How do the enviro-toons define the ecojustice problem? Do they offer conclusions or appropriate solutions? 4) How do cartoons (especially USA animation over the past century) engage viewers in consideration of environmental issues? Animation's function is to "question and challenge received knowledge which govern the physical laws and normative socio-cultural orthodoxies of the real world" (Wells 1998: 5). Accordingly, a visual expression moves beyond the identifiable restrictions and limits of the material world in order to critique them.

Ecocritical debate provokes new readings of the human/nature relations in motion picture. The focus of the present paper is on the poetics of enviro-toons, that is, not only what cartoons show but how they illustrate ecocritical sensibility and how it affects the way of 'seeing' and understanding the human/nonhuman world. Finally, the present paper is an attempt to fill in a gap in Ecocriticism which until recently has focused on literature defined as Nature Writing; poetry, fiction and drama. Yet, with the move toward ecocritical Film Studies, there is a place for work on animated feature films.

\subsection{From Ecocriticism to Ecoanimation}

Historically, Western beliefs in the right to exercise dominion over the environment have been shaped by GrecoRoman traditions which privileged humans as the "measure of all things" as indicated in the Judeo-Christine beliefs derived from the biblical Book of Genesis 1:26 to assert the anthropocentric position of human mastery and control over the natural world (Stephens 40) in a hierarchical relationship that perpetuates the ideologies of Utilitarianism and within the dominant discourse of industrialism. In The Politics of the Earth (2005), John Dryzek identifies human needs and demands that are being continually satisfied through the 
Screening Nature in Walt Disney's Bambi (1942) and Dr. Seuss's The Lorax (1972): An Ecocritical Approach to Enviro-toons

Dr. Marwa Essam Eldin Fahmy Alkhayat

مجلة وادي النيل للاراسات و البحوث الإنسانية والاجتماعية و التربوية (مجلة علمية محكمة)

manipulation of the environment within the following Promethean metaphor: "In Greek mythology, Prometheus stole fire from Zeus and so vastly increased the human capacity to manipulate the world" (51). Dryzek's metaphor is underpinned by an assumption that the humans' role is to have dominion over a cornucopian environment. This Western legacy of tragic anthropocentric discourse has led to monologic and 'readerly' tales of humans overcoming difficult odds to succeed in the end, thereby; it has led to environmental devastation.

With the rise of the environmental movement, ecology has become popular and has been adopted by other critical discourses such as Feminism, Postcolonialism and Animal Studies. Ecocriticism - as a discipline - is an ecological growth of Post-Structural criticism that studies human representations of nature and it has begun as a mode of literary criticism committed to observing narrative patterns and stories that impact human awareness of and engagement with environments. In the "Introduction" to The Ecocriticism Reader (1996), Cheryl Glotfelty explains that Ecocriticism is rooted in a desire to contribute to the kinds of cultural changes that lead to changed actions: "How then can we contribute to environmental restoration, not just in our spare time, but from within our capacity as professors of literature?" (Italics mine xx-xxi). When literary studies have seized ecology, Ecocriticism has emerged to study the relationship between literature and nature taking "an earth-centered approach" (Glotfelty xviii). Man - being part of the ecosystem - is "neither master nor slave to it, but simply one part of an intricate system" (Klue 1).

Ecocriticism originated in the USA largely from the need to study environmental non-fiction called Nature Writing. Ecocriticism's official beginnings are often recognized with 
the founding of the organization ASLE: "The Association for the Study of Literature and Environment" in 1992, followed by the organization's journal, ISLE: "Interdisciplinary Studies in Literature and Environment" in 1993 and with the publication of Cheryl Burgess Glotfelty and Harold Fromm's anthology The Ecocriticism Reader regarded as a landmark in literary ecology in 1996. Ecocriticism's aims are simple: to afford a community and "some academic legitimacy for the work of a new generation of literary scholars who have discovered, discussed and interpreted literary texts about environment; second, to examine representations of nature and environmental values in literary texts; third, to explore the interconnections between nature and culture; fourth, and most important, to respond to environmental problems and 'contribute to environmental restoration'" (Glotfelty xxi). Initially, this Ecocriticism attention has focused primarily on the environmental literature of adult. Slowly, an affiliated Ecocriticism of children's environmental literature began with a special issue of The Lion and The Unicorn on "Green Worlds: Nature and Ecology" (1995) and another special issue on "Ecology and the Child" in Children's Literature Association Quarterly (Winter 1994-1995). Although Ecocriticism has its origins in literature, it has been redefined with several other disciplines such as Ecoanimation - a subgenre of Film Studies - due to the growing presence of ecology as an academic discourse and the recent celebration of environmentalism. An ecocritical look into cartoons has begun to unfold within the field of what has been called 'enviro-toon' which examines cartoons with obvious environmental messages as themes.

Enviro-toons are "animated short or feature films that address environmental concerns" (Murray \& Heumann 2). The term 'enviro-toon' was coined by cultural critic Jaime Weinman (2004) who sorts animation into two simple 
مجلة وادي التيل للاراسات والبحوث الإنسانية والاجتماعية والتربوية (مجلة علمية محكمة)

categories. Some cartoons are useful for depicting the complexity of ecological issues. Others represent "a terrifying type of kiddie show" (Murray \& Heumann 2). Weinman claims that enviro-toons "never preach" and "not only humanize nature but comment on the abuse of nature and the natural, especially by humans" (Murray \& Heumann 2) and do engage with the repercussions of progress in the postmodern world. Just as verbal texts are ideologically laden, visual/motion scenes are bound up with creeds of the culture in which they are produced and circulated. In Animation and America (2002), animation theorist Paul Wells argues that the best animated films "offer the greatest potential for expressing a variety of divergent points of view, while at the same time accommodating a dominant paradigm of established social meaning" (2002a: 13). As Wells proposes, a cartoon's "very status as an animation asks an audience to re-perceive supposedly everyday issues, themes and knowledge" (2002a:6).

The present study is an examination of Ecoanimation to endorse an environmental consciousness of seeing "problems from a synoptic contextual perspective" (Brereton 11) as well as from a visual/motion one in order to promote an ecological meta-narrative connecting human with their environment. A visual ecocritical approach reveals "the logic of the image, specifically because images have effects that words do not, effects that have 'real' ramifications" (Dorbin \& Morey 25). Pro-environment discourses present multimodal ecological cartoons as manifested in ecocatastrophe represented by the loss of Edenic environment that is at odds with economic authority of advanced capitalist societies. Post-war envirotoons of the 1940s and 1950s offer strong critiques of "environmental devastation and negative consequences of progress" (Murray \& Heumann 52) and have taken strong 
مجلة وادي النيل للاراسات والبحوث الإنسانية والاجتماعية والتربوية (مجلة علمية محكمة)

(ISSN : 2536 - 9555)

stands on conservation issues: "environmentalism was a growing concern before, during, after World War II, at least in the world of animated film" (Whitley 68).

\section{Animation Aesthetics: 'The Art of Movement'}

Applying scholarly approaches to animated texts is more than a frivolous exercise; it is one that benefits an understanding of how environmental realities might be represented in profound and useful ways for a wide, engaged audience. (Pike 21)

I mean by animation aesthetics the amalgamation of character design, music, images and sounds as signs to convey subtly the artists' consciousness, styles and animated space. The semiotician Yuri Lotman regards animation as a specific system: "[T]he animated cartoon is not a variety of the feature cinema but represents a quite independent form of art, with its own artistic language [and] the basic property of the language of animation is that it operates with a sign of a sign" (36-37). Academic work on animation, as a subset of Film Studies, is interesting as it encourages a reexamination of the question: are such neglected subjects' areas 'worthy' of academic study? In Animation, Art and Industry (2012), Maureen Furniss declares that "bringing objects to life has fascinated humankind since its earliest days [and] throughout the years, animated movement has been employed in religious, scientific, educational and entertainment contexts to explain everything from the spirit world to the mechanics of mundane objects" (8). Despite being described as children's entertainment; animation was not originally aimed at a child audience. It is a significant part of the development of popular cinema.

In Art in Motion: Animation Aesthetics (2008), Maureen Furniss states that by the 1910 s cel and paper animation 
dominated the form. She explains that "cel animation (today largely displaced by computer animation) is so called because animators draw objects, subjects and background on separate sheets of transparent celluloid acetate sheets called cels (patented by Earl Hurd and J. R. Bray in 1915) which are laid on top of one another in order to save time in an extra ordinarily labor intensive medium (one second of film can equal 12-24 individual drawings)" (16). In The History of Animation: Enchanted Drawings (1994), Charles Solomon writes that animation creates the 'illusion of life' through movement. He further explains that there are two unique features:

First, the image is photographed on film 'frame by frame' and second; in consequence, the illusion of motion is created cinematically rather than recorded. He analyzes that in animation, a special camera is used that can photograph one frame at a time. Between exposures, the animator incrementally moves an object: it can be cels, puppets, clay, sand or paper cuts outs, but the basic principle is that the illusion of motion is constructed. That is, rather than photographing something that is already moving, movement is created in the camera through stopmotion photography, or the photographing of an object frame by frame. (9-12)

Animation is not "the art of drawing that move, but rather the art of movements that are drawn. What happens between each frame is more important than what happens on each frame" (Solomon 11). Thus, animation is art in movement and more precisely, it is the 'art of movement' and the term 'animated film' means not "just cartoon, but any motion 
مجلة وادي النيل للاراسات والبحوث الإنسانية والاجتماعية والتربوية (مجلة علمية محكمة)

(ISSN : 2536 - 9555)

picture film" and "animation [have] become recognized as a distinct type of filmmaking" (Thompson 106).

In Understanding Animation (1998), Paul Wells elucidates that "animation is derived from the Latin term 'animare' meaning 'to give life to', that is, animation infuses the inanimate with 'spirit"'(10). He highlights the unique abilities of animation to "redefine the everyday, subvert our accepted notions of 'reality' and challenge the orthodox understanding and acceptance of our existence". Animation offers limitless possibilities and it does not confine to temporal or spatial continuities, in other words, animation's ability is "to violate and compress any notion of time and space" (Wells 1998: 19). This underlies "the freedom of expression articulated through animated films or cartoons: the rejection of definite form challenging social order, the use of metamorphosis and the ability to assume any shape and volume, a condition labeled 'plasmaticness"' (Wells 2002b: 41). Animation is manifested in different styles and modes as it can be lyrical, fantastic, abstract, experimental, realistic or non-narrative. It is evident that animation is a medium which is capable of telling stories in a variety of ways. The idea of a "story" can therefore be understood as "a sequence of events taking place over a period of time; events can be presented in a multiplicity of ways in animation, to convey different meanings and/or emotions while utilizing distinctive characteristics of animated narrative such as metamorphosis, fabrication, associative relations, sound, symbol, and metaphor" (Wells 1998: 68).

Wells categorizes animation into three areas: orthodox (narrative based on cel animation), developmental (narrative based on clay, puppet, collage animation) and experimental (non-objective, non-linear or abstract animation). He specifies two extremes of animation: "orthodox" and its "antithetical equivalent" as experimental which frequently strives for an 
Screening Nature in Walt Disney's Bambi (1942) and Dr. Seuss's The Lorax (1972): An Ecocritical Approach to Enviro-toons

Dr. Marwa Essam Eldin Fahmy Alkhayat

مجلة وادي النيل للاراسات والبحوث الإنسانية والاجتماعية والتربوية (مجلة علمية محكمة)

'opposite effect' while the in-between of these two extremes would be regarded as developmental (Wells 1998: 36). Wells's theory of animation can be configured in the diagram below:

\section{Theory of Animation}

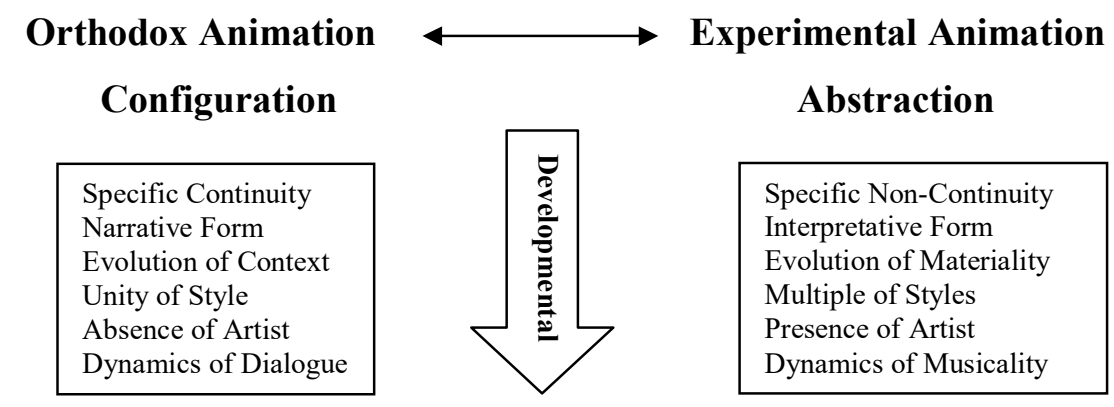

Figure 1

Orthodox animation refers to animation that seems more conventional and marketable than its counterpart. Orthodox animation describes the sort of animation in terms of realistic characters, settings and objects that can be watched on television or in the cinema. On the other hand, experimental animation characteristically presents figurative/symbolic representations, poetic images and the abstract meanings often have to be interpreted by the viewer himself. Animation is an eloquent language that has the power to repress rationality and experimental animation can arguably achieve this more effectively with its abstract nature as illustrated in the two tables below: 
Table 1

\begin{tabular}{|c|l|}
\hline \multicolumn{2}{|c|}{$\begin{array}{c}\text { Orthodox Animation } \\
\text { Conventional \& Marketable }\end{array}$} \\
\hline Configuration & $\begin{array}{l}\text { Characters are realistically identified and with } \\
\text { whom the viewers emotionally involved }\end{array}$ \\
\hline $\begin{array}{c}\text { Specific } \\
\text { Continuity }\end{array}$ & $\begin{array}{l}\text { The animation is linear, sequential, chronological } \\
\text { and logical }\end{array}$ \\
\hline Narrative Form & $\begin{array}{l}\text { A story with a problematic situation and is } \\
\text { resolved at the finale }\end{array}$ \\
\hline $\begin{array}{c}\text { Evolution of } \\
\text { Context }\end{array}$ & $\begin{array}{l}\text { Character depiction is prioritized over } \\
\text { construction }\end{array}$ \\
\hline $\begin{array}{c}\text { Absence of Artist } \\
\text { Rarely enhancing the significance of the creator's } \\
\text { authorial mark }\end{array}$ \\
\hline Unity of Style & $\begin{array}{l}\text { Consistency, steady rhythm, continuous regularity } \\
\text { and a monologic discourse }\end{array}$ \\
\hline $\begin{array}{c}\text { Dynamics of } \\
\text { Dialogue }\end{array}$ & $\begin{array}{l}\text { Characters are identified by key aspects of } \\
\text { dialogues, actions, mannerisms }\end{array}$ \\
\hline
\end{tabular}

Figure 2

Table 2

\begin{tabular}{|c|l|}
\hline \multicolumn{2}{|c|}{$\begin{array}{c}\text { Experimental Animation } \\
\text { Symbolic \& Hyperbolic }\end{array}$} \\
\hline Abstraction & $\begin{array}{l}\text { Resisting orthodox animation since characters are } \\
\text { symbols of realities they represent }\end{array}$ \\
\hline $\begin{array}{c}\text { Specific Non- } \\
\text { Continuity }\end{array}$ & The animation is non-linear, illogical and irrational \\
\hline $\begin{array}{c}\text { Interpretative } \\
\text { Form }\end{array}$ & $\begin{array}{l}\text { Viewers are invited to use their imagination to } \\
\text { interpret the animation and to fill in visual gaps }\end{array}$ \\
\hline $\begin{array}{c}\text { Evolution of } \\
\text { Materiality }\end{array}$ & $\begin{array}{l}\text { Construction is prioritized over character } \\
\text { delineation, instead there is symbolic imagery }\end{array}$ \\
\hline $\begin{array}{c}\text { Multiple of Styles } \\
\text { Presence of Artist } \\
\text { pluralistic discourse }\end{array}$ & $\begin{array}{l}\text { Authorial signature is evident in the construction } \\
\text { and the creation of the Animation }\end{array}$ \\
\hline $\begin{array}{c}\text { Pynamics of } \\
\text { Musicality }\end{array}$ & A strong relationship between music and animation \\
\hline
\end{tabular}

Figure 3

46 
Screening Nature in Walt Disney's Bambi (1942) and Dr. Seuss's The Lorax (1972): An Ecocritical Approach to Enviro-toons

Dr. Marwa Essam Eldin Fahmy Alkhayat

مجلة وادي النيل للاراسات والبحوث الإنسانية والاجتماعية والتربوية (مجلة علمية محكمة)

Consequently, the peculiar language of animation is deliberately defined by multiple distinctions. The language of animation remains "particularly expressive with modernist credentials: enunciating difference and otherness while employing storytelling devices such as metamorphosis, sound, metaphors, [and] symbols" (Wells 1998: 21). The way in which these two contrasting extremes of animation, orthodox and experimental, are used to tell a story varies tremendously as exemplified in the two selected enviro-toons. It has been argued by some film historians, such as William Moritz, that true animation is in the abstract form, yet, this has been counter-argued by the fact that animation in essence means "to give life to". It is acknowledged that orthodox animation achieves "this more realistically with further importance placed on the concept of character depiction, storyline configuration, and significantly movement - which will always remain a pivotal defining aspect in animation" (Wells 2002b: 6).

My study examines animation as an aesthetic device in the light of media scholar Marshall McLuhan's categories of "hot" or detailed, high resolution media and "cool" or low resolution media. Hot and cool media differentiate between a highresolution medium that frames reality with so many details which the audience might accept more passively and lowresolution medium that requires audience to work furiously to fill in its details (McLuhan 18). A hot medium explodes human experience in physical and cultural senses. It is a medium "that extends one single sense in 'high definition'". McLuhan uses the term "high definition" to refer to "media jam packed with data, rife with details packing more pixels, facts or bits of data per inch than ever" (McLuhan 22). The hot medium, McLuhan argues, also shares some of the 
attributes that Roland Barthes describes as those of a "readerly" text. A "readerly" text plunges its user into "a kind of idleness - he is intransitive [and] instead of functioning himself, instead of gaining access to the magic of the signifier, to the pleasure of writing, he is nothing more than a referendum" (Barthes 4). In contrast, cool medium sketches symbols of realities they represent: "imagination is put to work on behalf of filling in the blanks" creating a "richer experience and the audience are invited to join the narrative" (McLuhan 23).

Within this rationale, hot-medium can be seen as a monologic discourse while cool-medium can be regarded as dialogic and pluralistic so as to build heightened awareness through subtle messages about the power of nature over human world and the need for controlling human intervention as well as human exploitation. The Lorax as a dialogic envirotoon triggers action while Bambi is a monologic biography in photographic realism. The Lorax fits within the "cool" or low resolution media to reflect postmodern tenets and to establish a rebellious plural discourse. The Lorax decenters a capitalist society through the use of self-consciousness fragmentation, multi-layered irony and a strong opposition to authority to exhibit a distrust of totalizing hierarchy.

In the present study, Bambi is also juxtaposed with The Lorax regarding their inner build. This juxtaposition underlies a series of questions proposed by Furniss in tackling the structural design: "any analysis of the structural design of a work should consider first its primary function. Is it to entertain a wide audience? Is it to experiment and uncover new techniques or ways of thinking?" (Furniss 1998: 97). Disney's studio stands for the commercial animation with its constant rhythm and continuous regularity since orthodox animation prioritizes character construct and self-contained 
Screening Nature in Walt Disney's Bambi (1942) and Dr. Seuss's The Lorax (1972): An Ecocritical Approach to Enviro-toons

Dr. Marwa Essam Eldin Fahmy Alkhayat

مجلة وادي النيل للار اسات والبحوث الإسانية والاجتماعية والتربوية (مجلة علمية محكمة)

narrative. Within the illusion of realism framework, Wells believes that Disney's animation can be called "hyper-real" (Wells 1998: 25). He believes that Disney's animated space is artificial and it exists independently of the real world, yet, it represents reality. In contrast, Seussology represents animation structure that is non-realistic, complex and fantastic since experimental animation prioritizing the illogical and the irrational.

Eventually, animation is an aesthetically determined lexis, interpreted by different animators, hence, animation bears a distinct authorial signature and a unique studio style. Disney's Bambi (1942) and Dr. Seuss's The Lorax (1972). Disney's 'realist' style fits into orthodox animation while that of Dr. Seuss is dialogic, abstract and experimental, a contrast that can be envisioned in the chart below:

\begin{tabular}{|l|l|}
\hline \multicolumn{1}{|c|}{ Bambi (1942) } & \multicolumn{1}{c|}{ The Lorax (1972) } \\
\hline An allegory of Post-War Europe & A metaphor of American capitalist ethics \\
\hline Photographic realism & An abstract/fantastic enviro-toon \\
\hline A monologic biography & A dialogic/pluralistic enviro-toon \\
\hline A visual lyrical poem & A dream-like state \\
\hline A readerly enviro-toon & A writerly enviro-toon \\
\hline Pastoral misè-en-scène & $\begin{array}{l}\text { Imaginary environment, make-believe } \\
\text { creatures and odd-name objects }\end{array}$ \\
\hline
\end{tabular}

Figure 4

It is noted that Disney "insisted on verisimilitude in his characters, contexts and narratives" picturing "animated figures to more like real figures and be informed by a plausible motivation" (Wells 1998: 23). Yet, both Bambi and The Lorax work with ecosublime in a unique fashion to experience the Awe of Nature that has been destroyed and to 
مجلة وادي النيل للاراسات والبحوث الإنسانية والاجتماعية والتربوية (مجلة علمية محكمة)

(ISSN : 2536 - 9555)

question the frail hierarchy of the human/nonhuman world illustrated as a battle between life and death.

\section{Disney's Bambi (1942): A Signifier of a Sentimental Nature}

In The Idea of Nature in Disney Animation (2008), David Whitley refers to the historical/political background of Disney's Bambi (1942) which is considered as an allegory for Post-War Europe. The bombing of Pearl Harbor had brought the United States decisively into engagement in World War II. Just as the war ravaged communities, the forest community also faces the danger posed by Man, the villain who is ethically flawed: "Though Bambi is not in any obvious sense about war, its feeling for a pure, natural world is a retreat from aggressive and predatory human instincts" (Whitley 74). Bambi belongs to the features of wartime years and it suffered from financial crisis due to the greater production budgets and the loss of European markets caused by World War II. In the face of this war, Bambi's artists deployed magic in pursuit of a more humane ideal and found it in a delineation of nature that emphasizes strong family bond, community and peaceful existence. Thus, Bambi is a somber allegory of human violence and it breaks away from "cartoonish animals and creates something more realistic" (Johnston \& Thomas 142). Bambi cherishes iconic significance within debates about hunting and it has been recognized as the most important of all Disney's films dealing with wild nature in which Man is always referred to as "He" to signify the predatory deity of this harsh world. Ralph Lutts acknowledges that Bambi has become "one of the most emotionally, powerful national symbols of nature, one that motivates deep concern and dedicated action to promote wildlife" (160).

The role of fantasy is pivotal to expose an anthropocentric sentiment towards forest animals with human attributes. The 
masterpiece shot visualizes the fearful stare of the grazing deer. Bambi and his Mother are shown eating the new spring grass that is growing in the snowy open space of the meadow. This medium shot - angled from above the ground level so that viewer looks down on the grazing animals - is distinctive and makes the spectator keenly aware of their weakness. The effect is reinforced in shots which show the adult deer raising her head repeatedly and apprehensively as she scrutinizes the landscape for signs of possible menace. A few seconds later, the animals flee in alarm and the camera follows their flight at medium distance in a continuous tracking shot. Bambi's Mother's death takes place off camera while the viewer continues to follow the young deer's flight to safety in the heart of the forest. At this point, the surroundings are delineated in full sensuous detail. The richness of 'home environment' is poignant. The snow - which begins to fall heavily - blurs perception of the surrounding environment in a mode that is analogous to eyes becoming watery with grief to symbolically lament the death of Bambi's Mother.

This visual metaphor is an emblem of the Western trope that associates the environment with the female or tends to gender the physical world as female. Coding nature as female is not just Western but universal through the association with nature's reproductive capacities. In "Naturalized Woman and Feminized Nature" (2000), Kate Soper claims that the female metaphor identifies the environment with a body of scientific laws, principles, and processes. The environment is, therefore, understood as an object of scientific scrutiny and experimentation. The gender metaphor is drawn-out "when understandings of the environment as a sexual object are prompted by spatial associations that link female metaphors of the environment with physical territory" (Soper 139). Understood in both these ways, the environment may be 
realized as "the potential spouse of science, to be woven, won, and if necessary forced to submit to intercourse" or a "source of erotic delight" in the sense of territory that can be penetrated, tamed and tilled (Soper 141).

However, further semantic tension arises when the environment is represented metonymically in line with the Romantic tradition as Mother. Nature to Wordsworth, for example, is "a mother-goddess who teaches the soul serenity and joy, and never betrays the heart that loves her" (Gleckner \& Enscoe 17) as revealed in The Prelude. Nature is also seen as "a quasi-religious mysticism" (Darcy 214) worthy of respect and reverence. In this sense, Bambi is "a version of Eden myth" (Whitley 61) and the forest is conjured with "a kind of joy and lyrical delight appropriate for the representation of unfallen nature within paradise" (Whitley 61). The rise of nature worship in many ways reflects a "foreboding of impending loss, a melancholic anticipation of the advances of natural world" (Bunce 191).

Biophilia is interrelated with anthropomorphism to enhance environmental awareness. Anthropomorphism includes personification, characterization and narrative structure and it is also inseparable from the wildlife filmmaking process. When animals are filmed, they are removed from their natural environment and are placed within "a human construct of characterization and personification, emotive music and the imposition of a narrative structure- all place human-like motivations and emotions on animals" (Mitman 1999). How animals are anthropomorphized on screen may reveal more about the filmmakers' choices and cultural background than the reality of natural world and animal biology. Bambi is a "Disneyified animal" (Cartmill 162) and the shaping influence of the use of anthropomorphic trope lies not only in overt expressions of personification, but also in the animal protagonist's ability to think, feel, communicate and behave as 
a human being. In springtime, forest animals - Faline, Thumper and Flower - become crazy with love to encounter their beautiful romantic counterparts. When Bambi looks in the pond, he perceives Faline's reflection as well as his own. Faline laughs and Bambi halts in wonder and blinks twice. Unfortunately, their courtship is quickly interrupted by an aggressive older stag named Ronno who attempts to force Faline away from Bambi. Bambi successfully manages to defeat Ronno in a battle gaining the doe's affections. The only natural predator represented is the owl that is "a kind of grumpy, middle-aged guardian of forest life, the most aggressive act is to hoot at a group of amorous birds who are disturbing his spring time peace" (Whitley 61).

Bambi revolves around the cycle life of Bambi baby, young, adult in a lyrical and epic fashion. Grown up at his Mother's side, the animated fawn is troubled by cartoon droplets of rain falling. The soundtrack punctuates the falling raindrops with the notes of a clarinet and a full orchestra plays "April Showers", a merry tune. Rain is a focal part of nature's cycle in this rhapsodic depiction of wilderness. The fierce storm stops and gentle creatures of the forest emerge from nests and thickets. The whole poetic ambiance is lovely and serene in the visually stunning forest portrayed with an unprecedented attention to realistically drawn detail. The serenity of the opening scene contrasts starkly with Bambi's later visits to the meadow, a wonderful place made tense by the potential danger. The meadow menace is also chaotic and thoroughly human. On hearing the sounds of the gunshots, forest animals flee and Young Bambi asks his Mom about this danger: "Man [dramatic pause] was in the forest", Mom explains. In this enviro-toon, invisible humans are villains who shoot and set fires to threaten the forest animals: "Human beings are mere interlopers in nature, their presence in the 
movie reduced to the feet of the hunters who kill Bambi's mother and later start the devastating forest fire [bringing] only death and destruction to the pristine Eden inhabited by the benign and gentle animals" (Ingram 19), thus, the message is a jeremiad; an awe-inspiring natural balance is in peril because of the irresponsible human actions.

Bambi can be read as a monologic enviro-toon that perpetuates a romanticized view of nature and positions human species as corrupt and callous in a motion picture ecotragedy. Bambi proposes that humans and nature remain separate. The monologic stand reveals that there is no move toward interdependence between the human and the nonhuman. This one-dimensional side of the intellectual paradigm does motivate "deep concern and dedication action to promote wildlife", but this sentimental image is a distorted one since "the reality of nature as understood by contemporary scientific ecology is chaotic and unstable" (Ingram 19). Within this rationale, Lutts writes that the film is "an empty symbol because the concept of nature that Disney's fawn represents is impoverished [hence] Bambi motivates, but it does not educate, it may stimulate action, but not understanding" (169). The film is "impoverished" as key aspects in the real natural world are seen through a seriously distorting lens despite the artistic care to render a whole range of details naturalistically.

$B a m b i$ is based on children's novel by the German writer Felix Salten that was first published in English in 1928. Salten's Bambi is bleak and foreboding where violent death is part of the natural scheme of things. Humans are super predators who inflict destruction and devastation on the entire forest. Salten's pessimistic view of humankind's relationship to the natural world in the aftermath of World War I is not surprising, as he was one of many Europeans of his time who imagined consolation of a natural world devoid of the brutality of humankind. The original novel, written for an adult 
Screening Nature in Walt Disney's Bambi (1942) and Dr. Seuss's The Lorax (1972): An Ecocritical Approach to Enviro-toons

Dr. Marwa Essam Eldin Fahmy Alkhayat

مجلة وادي النيل للاراسات والبحوث الإنسانية والاجتماعية والتربوية (مجلة علمية محكمة)

audience, is considered too "grim" and "somber" for the young audience Disney was targeting (Barrier 269). Disney's version softens the gloomy environmental aspects found in the novel to imbue it with a brighter feeling and mood.

The addition of two new, sweet and gentle forest characters- Thumper the Rabbit and Flower the Skunkcontributes to give the film the desired friendlier and lighter feeling. The storyline of the film is different in its message. As in biblical Eden, Disney's nature's predatory, stinging and biting are almost absent. By associating predation to man's sin, Disney depicts man's devastating and evil influence on nature. In terms of lessons of survival conveys key messages to the viewers, the Old Prince's lessons of how to release animals caught in snares and how to avoid the traps of Man are very insightful to Young Bambi. When Bambi is later shot by a mysterious hunter, the Prince teaches him how to walk in circles to perplex Man and his dogs until the bleeding stops, and then to hide in a safer habitation to recover. They remain together until Bambi is strong enough to leave the safe haven again. The Old Prince also demonstrates that "He" is not invincible by showing Young Bambi the dead body of a man who has been shot and killed by another man. In Wildlife Films (2000), Derek Bousè believes that Salten's novel - being based mostly on the Post-World War I nihilism - is an allegory for the "cold aura of pessimism" (142) of Post-War Europe. $\mathrm{He}$ also ponders that "Salten's Bambi, for decades seen as a realistic portrayal, is essentially a tale of friendship and community in the woods" (142). This notion of companionship enhances Salten's theory of creating an allegory for Post-War Europe based on the strong community bonds that tended to develop in Post-War societies. The forest community unites efforts to overcome the menace posed by Man. Disney added a new finale to Salten's novel: one of 
restoration and rebirth within Bambi's growth into adulthood to signify the continuous cycle of life.

The question that poses itself: is it right to judge fictional narratives for children according to rigorous criteria for verisimilitude? To my mind, it is very important to put in consideration the historical and political background of this eco-tragedy that drove the animators to follow that naturalistic and realistic pattern. The animation was released when U.S. military forces fighting against the Nazis in World War II. Bambi's setting seems, at first, far removed from the horrific landscapes of war-torn Europe. Birds sing and forest animals frolic ceaselessly in a romanticized nature. The eco-tragedy invokes nostalgia for nature anticipating ever worse catastrophe to come unless human societies regret for their debaucheries against nature and establishing a pleasantsounding relationship with the natural world. Disney's animation evokes a sense of a lost world of rural and small town American values. Nature as Mother environment is pristine, abundant and bucolic. The wilderness trope depicts environment as bountiful and the metaphor of female/mother earth and the pastoral wilderness fulfill a psychological need of biophilia, a love for the countryside. Cartmill postulates that Bambi has a "deep influence on modern attitudes toward hunting, wildlife and the wilderness" (180) to inaugurate a "philosophical era with a perspective that lauded the natural world as a special, mystical realm not available to human beings who have polluted nature through culture, technology and waste" (180).

Finally, Bambi goes to extraordinary lengths to imbue the natural environment depicted with a strong sense of realistic detail and Disney's animation is known for its pastoral misèen-scène to conduct 'anti-hunting' propaganda. Lutts states that "The Bambi complex, Bambi factor and Bambi syndrome" are used interchangeably for sentimental sympathetic attitudes 
Screening Nature in Walt Disney's Bambi (1942) and Dr. Seuss's The Lorax (1972): An Ecocritical Approach to Enviro-toons

Dr. Marwa Essam Eldin Fahmy Alkhayat

مجلة وادي النيل للاراسات والبحوث الإنسانية والاجتماعية والتربوية (مجلة علمية محكمة)

towards wildlife especially deer" (50). Lutts continues that these terms are usually used "derogatorily and reflect a backlash against the humane, anti-hunting and preservationist values and the excessive sentimentality that Bambi has often come to symbolize" (50). Bambi vilifies hunting and human hunters - delineated as shadowy murders - who burn down the animals' forest, thus, valorizing the rights of animals more forcefully than those of Man. Bambi's Mother is killed by Mr. Man and his sweetheart by Mr. Man's dog, finally his terrestrial paradise is destroyed by Man's fire. The eviro-toon's fire images can be considered as being fitting with what has become the dominant ideological locus by the 1930s and 1940s; fire is seen "as a destructive force with a detrimental and potentially devastating impact on wilderness environment" (Whitley 70).

\section{The Lorax (1972): From Ecotopia to Dystopia}

The Lorax (1972) is an animated musical television special word by word adaptation of Dr. Seuss's picture book The Lorax (1971) that marked the rise of the environmental movement in the seventies. Seussology refers to the artistic renderings of Dr. Seuss, the pen name of Theodore Seuss Geisel (1904-1991), an American political cartoonist and animator. He satirically focuses on the political and moral dilemmas of modern American overconsumption. The Lorax (1972) is about the rampart consumerism that serves as a sign of progress and devastation of the natural world. The Lorax leaves the viewers feeling ambivalent about the price of progress. Industrialization has widened the gap between nature and culture, between humans and the natural world. Nature, thereby, is seen as either a resource to be exploited or an enemy to be controlled. 
In the twenty-five-minute animated special, the depiction of the boy in white is juxtaposed with the decayed brownish wasteland in sepia tones. Unlike the picture book, the boy is farmed within a close-up shot to foreshadow his role as a savior and to signify the instinctive bond between Man and Nature. The motion narrative begins with a voice-over narration to introduce the "The Street of the Lifted Lorax" to arouse the viewer's curiosity to follow the boy's moves until he reaches the old Once-ler's Lerkim. This marks the shift to the Once-ler's reminiscences, that is, the shift from the frame story into the story of the mythical figure the Lorax in which the Once-ler is a storyteller or an embedded narrator and the boy becomes his implied listener. The old Once-ler confesses that his crazy greediness has caused "Smogulous Smoke", "Gluppity-Glupp", "Schloppity Schlopp" and he is also criticized for giving the Brown Bar-bar-loots "crummies in tummies"; all kinds of pollution as manifested in the deforestation of the Truffula trees and the departure of the forest creatures.

Dr. Seuss - speaking through his fanciful character the Lorax - warns against mindless progress. The Lorax and the Once-ler, as symbolic characters, are products of a playful imagination that is apparently nonsense, but this nonsense is taken seriously. The Lorax is the guardian of the forest while the villain Once-ler signifies modern American Capitalist ethics. The surreal enviro-toon is a metaphor of the environment as a 'resource'. The silky threads of the Truffula trees provide the entrepreneurial Once-ler with the perfect 'resource' for making the useless garment 'Thneed'. The large scale production of these garments eradicates the Truffula trees and creates a toxic environment incapable of supporting the 'poor-Smomee Swans' or the 'Humming-Fish' whose "gills are all gummed". The Once-ler - as a pro-industry characterpresents an economic growth model that incorporates mastery 
Screening Nature in Walt Disney's Bambi (1942) and Dr. Seuss's The Lorax (1972): An Ecocritical Approach to Enviro-toons

Dr. Marwa Essam Eldin Fahmy Alkhayat

مجلة وادي النيل للار اسات والبحوث الإنسانية والاجتماعية والتربوية (مجلة علمية محكمة)

without any notion of sustainability. This is an act of strong anthropocentrism that represents a discourse to interpret the world in terms of human values considering Man the most significant entity in the universe.

The Once-ler acts as a colonial landlord advocating a Promethean discourse based on the ideological assumption of human's dominion over the bountiful environment. The Onceler's entrepreneurial ability to create a demand for the useless garment 'Thneed' and the acquisitiveness of the consumers who purchase it ensure the destruction of the resource that produces the garment. The suffering and disappearance of the Truffula trees underscore anthropocentrism at its ugliest. The opening scene draws on the apocalyptic trope to depict both verbally and visually an ecocatastrophe where "no birds sing excepting old crows". It is, Dylan Wolfe argues, "the collision of ecology and the American myth that produce this 'ecological jeremiad'" (14).

The visual significance of the opening scene is to trigger the viewers' curiosity and to guide them to the old Once-ler's Lerkim. The animated narrative progresses through a series of flashbacks to describe how the impoverished environment has come into being and in so doing, the enviro-toon gives an ecological account of the importance of preserving biodiversity. Although the enviro-toon takes place in a single imaginary forest, there is "no doubt that this place exists and is modeled on the American frontier and the idea of biggering/ and BIGGERING/and BIGGERING/ and BIGGERING" (Henderson 136) manifested in the Onceler's expansion and the "opening of the American West" (Henderson 136) that have led to a state of alienation between the inhabitants and the natural world. By concluding with the opportunity to restore the balance by planting the last Truffula seed, the 
enviro-toon adopts environmental discourses of equilibrium and harmony.

Habitat destruction is set in an imaginary location where the enigmatic Lorax 'speaks for trees'. This fantastical environment is inhabited by odd-name objects and makebelieve creatures. Dr. Seuss's works are characterized by being loud with "noisy pictures and noisy language" (Nel 195). Dr. Seuss's energetic language and colorful illustrations seem to "affirm the child's need to make a mess" (Nel 195). He creates a "complex interweaving of symbolism and anagrams establishing a distinguished style typical Seussical" (Nel 195) that relies heavily on exaggeration as a poetic device to enhance absurdity that is thunderous and rambunctious. Dr. Seuss's worldview refreshes his Post-World War II audiences who exhibited a strong appreciation for the fanciful as well as challenging complex and philosophical themes (MacDonald, 49).

Within the visual dramaturgy and the theorization of the object in animation, the Truffula tree and the garment 'Thneed' are objects with personalities. The very engine of animation is to prescribe agency to objects to explore the "privileged relation between the object and its use and application in animated cartoon" (Cholodenko 31). The specific use of material objects works as a counter-realism to orthodox animation. Giving life to a wide array of objects such as the sweeter-like object Thneed and the marketing slogan 'You need a Thneed' signify the adulteration of natural resource, capitalism and exploitation of the environment. There are other objects such as Snuvv, Whisper-ma-phone, Super-AxeHacker. The imaginary city is full of colorful images of the Brown Bar-ba-loots, the Swomee-Swans and the Hummingfish as well as plants like Gickle-grass, Truffula trees, places

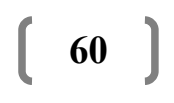


like Lerkim, North Nitch, and South Stitch. Suessian envirotoon is lexically rich, generous and full of deep philosophy.

To maintain the quality of experimental animation, Dr. Seuss gives little priority to the character depiction; instead, he uses characters for symbolic meaning to subtly 'speak' the motion narrative. Dr. Seuss himself comments upon his art: "I like nonsense; it wakes up the brain cells. Fantasy is a necessary ingredient in living, it is a way of looking at life through the wrong end of a telescope which is what I do, and that enables you to 'laugh at life' realities" (Geisel 2005). Dr. Seuss intentionally portrays concepts and ordinary relationships in an exaggerated manner to contribute apprehensive feelings and to evoke a multilayered and indepth representation of ecological crisis. The comic exaggeration mode provokes a "comic operation of dismemberment" (Bakhtin 24). By inverting the fixed discourse, the viewer's laughter has an outstanding power of "making an object come up close, of drawing it into a zone of crude contact where one can finger it familiarly on all sides, turn it upside down, inside out, peer at it from above and below, break open its external shell, look into its center, doubt it, take it apart, dismember it, lay out it bare and expose it, examine it freely and experiment with it" (Bakhtin 23). Thereby, the viewers are invited to be co-creators and get involved in the meaning-making process. Herein lies the vital strength of the visual pleasure and experience that trigger the faculty of critical thinking.

The Lorax - as an experimental enviro-toon - relies upon musicality within a non-linear structure. Musicality tempers the mood encouraging the viewers to decode and draw imaginative inner meanings from the animation. As a dialogic enviro-toon, there is a strong interwoven thread of emotive 
music and abstract motion picture enhancing a rhythmical montage and an aural experience with the development of leitmotifs. Sound pattern is also a recurring element and crucial aspects in creating neologisms to unleash linguistic creativity. Nel observes that:

The Once-ler's machinery goes 'Gullpity-Glupp' and 'Schloppity-Schlopp' which has the effect of 'glumping the pond where the Humming-Fish hummed!' The Lorax himself, choking on the 'smogulous smoke', speaks with a 'cruffulous croak'. The verb 'glumping' sounds like dumping clumps of goo, 'smogulous' turns 'smog' into an adjective, and 'cruffulous' sounds like crusty, huffing, wheezing old man. These words not only sound like what you mean - they're fun to say ... Taking rhyme, alliteration, consonance, and assonance to their logical extremes, Seuss reduces words to distracting from sense. (Italics mine 26)

Seussian rhetoric and word invention are manifested in the use of linguistic subversion, superlative patterns, repetitions and abundant alliterations to create a rhythmic tone in a witty style. Rhyme is fun and a pure joy that springs from of the sound of the buzzwords. Seussian farcical expressions enhance absurdity and chaos in the fantastical world that the characters inhabit. Dr. Seuss has embedded many upbeat, loud and attention-grabbing aesthetic elements as exemplified in the newly coined words of the Once-ler: "And, for your information, you Lorax, I'm figgering on biggering/ and BIGGERING/and BIGGERING/ and BIGGERING/ turning MORE Truffula Tress into Thneed/ which everyone, EVERYONE, EVERYONE needs". Once-ler's crazy obsession to "bigger" his business has caused the destruction 
of the Truffula Valley and paradoxically the collapse of the business itself. Obviously, nonsense animation can be seen as a "heretical mission" (Anderson \& Apseloff 94). This brings to the forth the function of green cultural studies as an active politico-cultural device in service of both nature and culture "by attempting to merge with the real or imagined subjectivity of a plant, animal, or mineral and of air, water, earth, and fire; it will also need to pull back and grant these beings and entities unromanticized difference, an autonomy apart from humans, a kind of privacy and regard heretofore granted almost exclusively to humans" (Hochman 16).

The Lorax - as a fantastic enviro-toon - exhibits the spirit of playfulness to rearrange the familiar world or to "challenge the 'sense of the adult world'" (Cott 28). Seussian fantasy or "logical nonsense" (Avery et. al. 248) is associated with the firm belief in the child's insane logic of creativity and the freedom of expression to enhance a strong liberal morale. This anarchy aims at deconstructing capitalist ideological hegemony through the use of animation seen as chaotic, surreal dreamscape. The cool medium of animation functions within the comic mode as a dialogic enviro-toon with subversive messages.

The solution to the ecological crisis at the finale is imperfect and incomplete. The repentant Once-ler hands off the environmentalist boy the last Truffula tree seed. Although the boy remains silent throughout the animated narrative, he activates the Once-ler's storytelling. The boy stands at the spot from which the Lorax has departed to reinforce moral human responsibility, an act that triggers a hypothetical question. What if the Once-ler appeared from his Lerkim, giving back the boy's payment for telling in flashback the story and united with him to plant the last Truffula seed to approve the Truffula 
(ISSN : 2536 - 9555)

forest's regeneration? The result would become one of intergenerational action. Even the outraged Lorax does nothing to face the Once-ler's damage of nature. The Lorax's sharp tongue is not appealing to the Once-ler's beliefs of progress and exploitation. Both are failures since they have not grasped that the ecosystem includes not only plants and animals, but also themselves. The Once-ler imposes upon himself a state of isolation due to his overwhelming sense of materialism. The Lorax vanishes to an unknown place and instead of 'speaking for the trees', he would have created a strong collaborative strategy to 'speak with others' to fight the Once-ler's colonial and ecological damages.

\section{Conclusion}

Ecocriticism has grown much broader in diversity and in scope to include all forms of literature as well as the visual and performing art. Recently, Animation Studies has been seen as separate from Film Studies. In Film Art: An Introduction (2004), David Bordwell and Kristin Thompson show how discussions of the animated film have evolved from mere nods to chapter sections that indicate how much animation has distinguished itself as a valid filmic form. What is unique is that ecoanimation lends itself to "investing the worlds of inanimate objects, of animals, of nature with real spirit and character" (Clarke 2) to illustrate the logic of the ecological image visually because the animated image has effects that words do not possess. The present study proposes an ecocritical reading of two enviro-toons to conceptualize the environment as a resource to underscore ecodegradation made by a greedy, selfish Man in Bambi and avaricious, acquisitive capitalist Once-ler who devastates a blooming landscape in an 'abstract' animation. 
Screening Nature in Walt Disney's Bambi (1942) and Dr. Seuss's The Lorax (1972): An Ecocritical Approach to Enviro-toons

Dr. Marwa Essam Eldin Fahmy Alkhayat

مجلة وادي النيل للار اسات و البحوث الإنسانية والاجتماعية والتربوية (مجلة علمية محكمة)

Not only does Dr. Seuss tell fantastical tales of far-away places but he also illustrates a unique visual language that carries his stories to new heights of artistic expression. Surrealism provides the foundation from which he builds the structure of The Lorax. The structure is analogous to a dreamlike state to underlie hidden sentiments beyond the orthodoxies of language. The child character has a central role in environmental awareness and activism, thereby, the boy in white and nature can be seen as "a joint construction of the essential" (Lesnik-Oberstein 208). The presence of the human agency can establish The Lorax as a dialogic enviro-toon to set an example of 'restrained anthropocentrism' to acknowledge warning signs in order to take an action. Discourses of sustainability have a threefold purpose: to offer hope of human survival; to critique environmental exploitation; and to propose human action to avert or redirect environmental crisis. The pro-environmental discourse towards 'eco-consciousness' develops attitudes of care and environmental awareness. This highlights the differences between 'strong anthropocentrism' and 'weak anthropocentrism', the latter is favored by environmental ethicists to bring the natural habitat back.

In contrast, Bambi is a monologic biography in photographic realism. Disney's mimesis and linear structure do not require deep interpretation and since it is only a warning with no handy action plan, there is no path to human redemption to exist in a world that upholds 'strong anthropocentrism' as a discourse of human dominion over nature. Disney's Bambi is a blatant critique of hunting practices, yet it presents "a visual poem exalting the glory of nature as seen in the cycle of seasons" (Maltin 66). Bambi is as an example of the wildlife enviro-toon that utilizes the 
natural and non-human landscape as a central motif in which stylized animals give way to more realistic portrayalsanimals are given distinctively human voices and emotions.

Ecocriticism is a stimulating arena of aesthetics, morality and politics. Herein lies its potential force as the environment has become an urgent and a timely academic issue. A fascination with wild nature has been regarded as "a scene of instruction, or of recovery or creation of supposedly deeper, truer, or more authentic identity whether understood in spiritual, political or often nationalist terms" (Clark 25). The preservation of the natural environment is a question of the good and the bad to define man's existence, thereby, it is a communal issue, not to be only tackled by the élites. Finally, Ecomedia Studies is a promising pop culture field not only geared to adolescents and children, but to the human community to be aesthetically interpreted against a monolithic approach.

\section{Works Cited}

Anderson, Celia and Apseloff, Marilyn. Nonsense Literature for Children: Aesop to Seuss. Hamden, Conn.: Library Professional, 1989.

Avery et al. Children's Literature - An Illustrated History. Peter Hunt (ed.). Oxford: Oxford University Press, 1995.

Bakhtin, Mikhail. Dialogic Imagination: Four Essays. Austin: University of Texas Press, 1981.

Barrier, Michael. Hollywood Cartoons: American Animation in its Golden Age. Oxford: Oxford University Press, 2003.

Barthes, Roland. S/z: An Essay. Richard Miller (trans.). New York: ill \& Wang, 1974.

Bate, Jonathan. Romantic Ecology: Wordsworth and the Environmental Tradition. London: Routledge, 1991.

Bousè, Derek. Wildlife Films. Philadelphia: University of Pennsylvania Press, 2000.

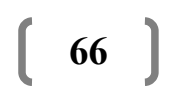


Screening Nature in Walt Disney's Bambi (1942) and Dr. Seuss's The Lorax (1972): An Ecocritical Approach to Enviro-toons

Dr. Marwa Essam Eldin Fahmy Alkhayat

مجلة وادي النيل للاراسات والبحوث الإنسانية والاجتماعية والتربوية (مجلة علمية محكمة)

Bordwell, David \& Thompson, Kristin. Film Art: An Introduction. Boston: McGraw-Hill, 2004.

Brereton, Pat. Hollywood Utopia: Ecology in Contemporary American Cinema. UK: Intellect, 2005.

Buell, Lawrence. The Environmental Imagination: Thoreau, Nature Writing and the Formation of American Culture. Cambridge, MA: Belknap, Harvard University Press, 1995.

Buell, Lawrence. Writing for an Endangered World: Literature, Culture and Environment in the U.S.A and Beyond. Cambridge, MA: Belknap, Harvard University Press, 2001.

Bunce, Michael. The Countryside Ideal: Anglo American Images of Landscape. London \& New York: Routledge, 1994.

Cartmill, Matt. A View to a Death in the Morning: Hunting and Nature through History. USA; Harvard University Press, 1996.

Clark, Timothy. The Cambridge Introduction to Literature and the Environment. Cambridge: Cambridge University Press, 2011.

Clarke, James. Animated Films. London: Virgin, 2004.

Cholodenko, Alan. The Illusion of Life: Essays on Animation. Sydney: Power Publications, 1991.

Cott, Jonathan. Pipers at Gates of Dawn: The Wisdom of Children's Literature. New York: Rando0m House, 1983.

Geisel, Theodor Seuss. Theodor Seuss Geisel: The Early Works of Dr Seuss. Miamisburg, Ohio: Checker Book Publication, 2005.

Darcy, Jane. "The Representation of Nature in The Wind in the Willows and The Secret Garden". The Lion and The Unicorn, Vol. 19, No.2, 1995, pp. 211-222.

Dorbin, Sidney \& Morey, Sean. Ecosee: Image, Rhetoric Nature. Albany: SUNY Press, 2009. 
Dryzek, John. The Politics of Earth. Oxford: Oxford University Press, 2005.

Furniss, Maureen. Art in Motion: Animation Aesthetics. New York: John Libbey Publishing Ltd, 2008.

Furniss, Maureen. Animation, Art and Industry. United Kingdom: John Libbey Publishing Ltd, 2012.

Gleckner, Robert \& Enscoe, Gerald. Romanticism: Points of View. Detroit: Wayne State University Press, 1962.

Glotfelty, Cheryl. "Introduction". The Ecocriticism Reader: Landmarks in Literary Ecology. Athens: University of Georgia, 1996.

Henderson, B. "Playing Seriously with Seuss: A Pedagogical Response to The Lorax". Wild Thing: Children's Culture and Ecocriticism. Sidney I. Dobrin, Kenneth B. Kidd (eds.). Wayne State University Press, 2004, pp. 128-148.

Hochman, Jhan. Green Cultural Studies: Nature in Film, Novel, and Theory. Moscow: U of Idaho P, 1998.

Ingram, David. Green Screen: Environmentalism and Hollywood Cinema. Exeter, U. K.: University of Exeter Press, 2000.

Johnston, Ollie \& Thomas, Frank. Walt Disney's Bambi: The Story and the Film. New York: Stewart, Tabori \& Chang, 1990.

Klue, Rachel. Man's Return to Nature. Athens: University of Georgia Press, 2008.

Lesnik-Oberstein, Karin. Writing the Environment: Ecocriticism and Literature. London \& New York: Zed Books, 1998.

Lotman, Yuri. "On the Language of Animated Cartoons" in Russian Poetics in Translation. Lawrence O'Toole Michael and Ann Shukman (Eds.). Oxford: Holdan books, 1981, pp. 36-39.

Lutts, Ralph. "The Trouble with Bambi: Walt Disney's Bambi and the American Vision of Nature". Forest and Conservation History, Vol. 36, No. 4, 1992, pp. 160-171. 
Screening Nature in Walt Disney's Bambi (1942) and Dr. Seuss's The Lorax (1972): An Ecocritical Approach to Enviro-toons

Dr. Marwa Essam Eldin Fahmy Alkhayat

مجلة وادي النيل للار اسات والبحوث الإنسانية والاجتماعية والتربوية (مجلة علمية محكمة)

MacDonald, R. K. Dr Seuss. Boston, MA: Twayne Publishers, 1988.

Maltin, Leonard. Of Mice and Magic: A History of American Animated Cartoon. New York: McGraw-Hill, 1980.

McLuhan, Marshall. Understanding Media. New York: McGraw-Hill, 1964.

Mitman, Greg. Reel Nature: America's Romance with Wildlife on Film. Cambridge; Harvard University Press, 1999.

Murray, Robin \& Heumann, Joseph. "Environmental Cartoons of the 193s, 40s, and 50s: A Critique of Post-World II Progress". ISLE, Winter Vol.14, No. 1, 2007, pp. 51-69.

Nel. Philip. Dr Seuss: American Icon. London: The Continuum International Publishing Group Ltd, 2004.

Pike, Deirdre. Enviro-toons: Green Themes in Animated Cinema and Television. Jefferson, NC: McFarland, 2012.

Rueckert, William. "Literature and Ecology: An Experiment in Ecocriticism". In Iowa Review 9, no. 1, 1978, pp. 71-86.

Russell, Bertrand. History of Western Philosophy. London: Unwin Hymn, 1996.

Seuss, Dr. The Lorax. New York: Random House, 1971.

Salten, Felix. Bambi: A Life in the Woods. New York: Simon \& Schuster, 1928.

Soper, Kate. The Green Studies Reader: From Romanticism to Ecocrtiticism. London: Routledge, 2000.

Solomon, Charles. The Art of the Animated Image: An Anthology. Los Angeles: American Film Institute, 1987.

Solomon, Charles. The History of Animation: Enchanted Drawings. New York: Random House, 1994.

Stephens, John. "From Eden to Suburbia: Perspectives on the Natural world in Children's Literature". Papers: Explorations into Children's Literature, Vol. 16, No. 2, ACLAR, Melbourne, 2006.

Thompson, Kristin. Implications of the Cel Animation Technique: The Cinematic Apparatus. London: MacMillan, 1980. 
مجلة وادي النيل للاراسات والبحوث الإنسانية والاجتماعية والتربوية (مجلة علمية محكمة)

(ISSN : 2536 - 9555)

Weinman, Jaime. "Things That Suck: The Smoggies". Something Old, Nothing New: Thoughts on Popular Culture and Unpopular Culture. Blogspot, 2004, http://zvbxrpl.blogspot.com/2004/09-things-that-suck$\underline{\text { smoggies.html }}$

Wells, Paul. Understanding Animation. London \& New York: Routledge, 1998.

Wells, Paul. Animation and America. Edinburgh: Edinburgh University Press, 2002a.

Wells, Paul. Animation: Genre and Authorship. London, New York: Wallflower Press, 2002b.

Whitley, David. The Idea of Nature in Disney Animation. UK: Ashgate Press, 2008.

Wolfe, Dylan. "The Ecological Jeremiad, The American Myth, and the Vivid Force of Color in Dr. Seuss's The Lorax", Environmental Communication, Vol. 2, No. (1): 2008, pp. 3-24.

\section{Filmography}

Bambi. Directed by David Hand. United States of America: Walt Disney Productions, 1942.

The Lorax. Directed by Hawley Pratt. USA: Columbia Broadcasting System (CBS), (TV), 1972. 